\title{
Mithridaticum and Mesir: The Story of an Antidote from Antiquity into Ottoman Times
}

\author{
Antikçă̆dan Osmanlı’ya bir Antidotun Hikayesi: Mithridaticum ve Mesir
}

Fatma ŞİMŞEK*

\begin{abstract}
The deadly and or beneficial effects of certain plants and animals were known from early times and in history possession of this knowledge was an element in the power struggles between ruling classes. King Mithradates VI Eupator of the Mithradatic Dynasty and his famous 'antidote' Mithridaticum against poisoning are frequently encountered and amongst the first to be mentioned in sources concerning medical history. After the occupation of the Mithradatic fortresses by the Romans, some books from Mithradates' library were brought to Rome and translated into Latin. This enabled this antidote of 54 ingredients to become widely known. Because one of the primary sources of classical Ottoman medicine was based upon the studies of Ibn-i Sina, known in the West as Avicenna, and of other Muslim physicians, we find mithridaticum also mentioned in Ottoman medical books. Some medical historians claim that mithridaticum gradually evolved into "mesir". In Ottoman folklore the mesir tradition was mostly associated with the personality of Merkez Efendi. When Hafize Sultan, Süleyman the Magnificent's mother, fell ill during the time when he was a prince in Manisa, Merkez Efendi, a physician in the hospital, healed her with the mesir paste he had prepared. And then there was the tradition of distributing mesir paste composed of 41 ingredients to people at the annual Newroz celebrations so that everybody could benefit from it. Mesir festivals are still organized today and are celebrated every March, remaining popular over the course of more than five centuries.
\end{abstract}

Keywords: Mithradates VI Eupator, mithridaticum, mesir, Merkez Efendi, Manisa

Özet: Bir takım bitkilerin ve hayvanların ölümcül/yararlı etkileri ilkçağlardan itibaren bilinmekteydi ve bu bilgi tarihsel süreçte egemen sınıflar arasında iktidar savaşlarının bir aracı halini aldı. Kuşkusuz bu alanda akla ilk gelen isimlerden biri, tıp tarihiyle ilgili antik kaynaklarda sıklıkla karşımıza çıkan Mithradates Hanedanlığı'nın en ünlü kralı VI. Mithradates ve onun zehirlenmelere karşı geliştirdiği “mithridaticum" olarak adlandırılan ünlü panzehirdir. Karadeniz Krallığı'nın kalelerini ele geçiren Romalıların, Mithradates'in kütüphanesinin bir kısmını Roma'ya götürmeleri ve eserleri Latince’ye çevirmeleri sonucunda 54 drog'tan oluşan ünlü panzehir tanınmaya başlanmıştır. Nitekim klasik Osmanlı tıbbının temel kaynaklarının büyük kısmı Ibn-i Sina ve diğer İslam hekimlerinin eserlerine dayanması nedeniyle mithridaticum 'unun, Osmanlı tıp kitaplarında da yer aldığı görülmektedir. Tıp tarihçilerinin bir kısmı zamanla kelimenin değişim geçirmesi ile "mesir" sözcüğüne dönüştüğü ileri sürmektedirler. Osmanlı halk kültüründe ise mesir geleneği daha çok Merkez Efendi etrafında şekillendirilmiştir. Buna göre Kanuni Sultan Süleyman'ın Manisa'daki şehzadeliği döneminde annesi Hafıze Sultan'ın hastalanması üzerine darüşşifada hekim olan Merkez Efendi, hazırladığı mesir macunu ile valide sultanı sağlığına kavuşturur. Böylelikle 41 çeşit drog'dan oluşan mesir macunun her yıl nevruzda dağıtılması suretiyle tüm halkın faydalanması amaçlanmıştı. Günümüzde de devam ettirilen mesir şenlikleri, her yıl Mart ayında tam bir festival havasında kutlanmakta ve popülerliğini geçen beş asra rağmen halen devam ettirmektedir.

Anahtar Sözcükler: Mithradates VI Eupator, mithridaticum, mesir, Merkez Efendi, Manisa

\footnotetext{
*Yrd. Doç. Dr., Akdeniz Üniversitesi, Edebiyat Fakültesi, Tarih Bölümü, Antalya, fsimsek@akdeniz.edu.tr
} 
Prior to the rise of modern medical and pharmaceutical sciences people understood and believed that God created both a disease and its remedy and so they attempted to treat illness with herbs, compounds and mixtures. They seem to have acquired the knowledge of when to use what natural material by observing the deadly/beneficial effects of plants, animals and inanimate objects (stones, minerals, metals, etc.), or through testing these remedies on themselves (Eyüpoğlu, 2007, 196). Plants formed the main type of material employed in the treatment of disease.

Later, in addition to natural materials and mixtures of them, pastes, produced through a variety of different methods began to be used effectively in the preparation of drugs because these pastes were easily used and preserved (Tez, 2010, 9). The knowledge and use of various pastes dates from ancient times with the earliest examples from India, Egypt and Sumer. These pastes were mainly prepared by holy men who were believed to possess supernatural powers, in order to equip people with heavenly and superhuman qualities rather than these pastes being employed in the course of healing people (Eyüpoğlu, 191, 193).

All this accumulation of experience, knowledge and technique, first employed in a pharmaceutical sense with the intention of finding a cure for illnesses, was soon to become a cause of bloody wars fought by ruling classes to gain power during the course of history. Undoubtedly Mithradates VI of Pontus and his famous antidote, mithridaticum have a unique place in this field (The word "pharma" meaning medicine is derived from the term "pharmakon", meaning both medicine and poison in Greek. See also, Tez, 2010, 9). Mithradates was the first experimental toxicologist known, as he tested his renowned antidote, created through the combination of both poisonous and beneficial ingredients, on his captives and slaves (Mayor, 2010, 58; 240).

Mithradates VI witnessed the suspicious death of his father Mithradates V. Euergetes and, in consequence he took refuge in the mountains, as he was afraid of being murdered by his mother Laodike, and he lived on wild plants (Prior to Mithradates, kings such as Attalos III of Pergamon, Nikomedes of Bithynia and Antiokhos of Seleukos developed an interest in toxicology and even established laboratories. See also, Arslan, 2007, 521). It is quite likely the experience he gained in the wilderness helped him to enlarge his knowledge of plants. When Mithradates was wounded during the war against the Scythians, the Scythian physicians cured him using snake venom, and this might also have contributed to his interest in poisons (Mithradates VI tried to improve his knowledge of toxicology by inviting famous contemporary physicians to his palace and corresponding with wellknown physicians such as Asklepiades. See also, Terzioğlu, 1999, 367; Arslan, 2007, 520). Every morning he used to drink a mixture containing wallnuts, figs and rue, which was prepared in accordance with his own prescription, after having added to it a little duck blood and a pinch of salt. Mithradates, who always remembered the assassination of his father, drank his specially concocted antidote when he attended banquets and feasts (The King preferred duck blood because he had observed the ducklings of Pontus gradually make themselves immune to poisons through consuming poisonous plants in small quantities. Terzioğlu, 1999, 367; Arslan, 2007, 522, 524). This antidote enabled him to have a strong and healthy body, as well as building his resistance to the effects of any kind of poisons in the long term. The ancient sources record that the king was hardly ever sick or wounded and when he was, he quickly recovered. Soon after he realized that the war was going in favor of the Romans, Mithradates VI committed suicide together with his two daughters, through drinking the poison that he always carried with him. Although the girls died instantly, he wasn't that fortunate, as he had developed his resistance to poisons and, in consequence, he had to have his bodyguard kill him with a sword (Arslan 2007, 506).

The Roman commander Pompeius, who occupied the Pontus fortresses, took some of the books from Mitridates library to Rome and these books were translated into Latin. This resulted 
in the gradual recognition of Mithradates' famous antidote, mithridaticum of 54 different ingredients (Totelin, 2004, 4; Arslan, 2007, 522, 523; In his book T. Baytop $(1999,18)$ writes that mithridaticum contained 48 ingredients). This mixture developed by the king should not be understood as a medicine but rather as a formula against poisons (Vahid, 1324, 3-4). Over the course of time Roman physicians made some changes to this compound. The most famous of these recipies was the prescription prepared by Andromachus, Nero's private physician in the I $^{\text {st }}$ century A.D. He concocted a mixture called "theriaca" (tiryak) through adding to the mithridaticum compound an additional 15-20 ingredients and serpent's flesh (In the 1837 French codex the number of ingredients in tiryak was 71; see also Baytop, 1999, 18. Bayat 1998, 68: The use of serpent's flesh in a remedial sense, can remind of the story and motif of the "Echidma"). Tiryak is first mentioned in Galens' "De antidotis", a collection of writings on poisons that relied upon the information which was provided by Krateus, Mithradates' private physician. In consequence these complex pharmaceutical antidotes began to be called mithridaticum (Bayat, 1993, 12; Tez, 2010, 139). Although mithridaticum and tiryak are sometimes confused, due to the similarity of the ingredients which they contain, one of the main differences is that tiryak includes snake's flesh, while in mithridaticum skink (surat alaskankur) was used (Terzioğlu, 1999, 369). Another difference between them is that tiryak was more effective in combatting snake venom than was mithridaticum (Bayat, 1998, 69). How the different versions of tiryak were employed was naturally different (According to the Roman medical writer Celsus' mithridaticum prescription, a wallnut-sized mixture was to be added to wine and was to be drunk everyday. See, Dalby, 2004, 218).

Tiryak, one of the most popular drugs of the Middle Ages, were different versions of mithridaticum and were generally used to prevent any kind of illness, mainly to ward off the Black Death and to cure venomous bites (Tez, 2010, 128). This tradition was so strong that the preparation of tiryak became a ceremonial event, performed on certain days of the year in some European cities such as Venice, Naples, Madrid and Paris. Venice held the licence for concocting tiryak for a long time and in the $16^{\text {th }}$ century during the festivals organized in the spring, this paste was prepared in front of the people to guarantee its genuineness, and it was exported to many countries under the name "theriaca veneta" (Baytop, 1999, 18; Tez, 2010, 162).

Between the VIII ${ }^{\text {th }}$ and $\mathrm{X}^{\text {th }}$ centuries both medical and pharmaceutical works that had been written in Greek and Latin were translated into Arabic and consequently western knowledge passed to the eastern world. Since some technical terms were somewhat transformed in the proccess of their translation into Arabic, mithridaticum became "misridates", "misiridates", "misroditos", "misruditus" and "misriditus". In this context the compound mithridaticum, with some minor variations, is found in the prescriptions of important Muslim physicians such as: Taberi, Mecusi, Ibn Hubel and Antaki (Bayat, 1998, 68). It is known that Ibn-i Sina (Avicenna), the greatest physician of the East, benefited from the earlier Arabic formulas or from the prescriptions which had been translated from Syriac and Greek into Arabic, when he was preparing his drugs (Uzel, 1986, 14). In his influential major work, "El-Kanun Fi't-Tibb", he mentions mithridaticum as "El-Masruditus" (Ibn-i Sina, 2010, 12). In "Edviye-i Kalbiye" Ibn-i Sina again mentions mithridaticum when he wrote on heart medicines and underlines its heart, stomach and liver-strengthening effect, because of the preventative features of the compound against both snake and scorpion venom (But we notice certain differences in the contents of the mithridaticum mentioned in classical Islamic works and the Greek and Latin sources. For example, while there are 13 ingredients in Ibn-i Sina's prescription: garikun, surincan, sezab-l yabis, uşak, dinktamayin, asarun, kesira, ustuhudus, kemfaytus, iklilü'l-melik, idan'ül-belesan, fülfül-i esved and mukl, Galen's list contains: aslu's-sus, milh which are absent from Ibn-i Sina's list and in another of his lists there is no mention of, bezrü'l-sezab. Bayat, 1998, 71). The 
mithridaticum compounds found in Classical Islamic medical prescriptions carry traces of those compounds mentioned by the antique sources, Demokrates and Diakinkum (Terzioğlu, 1999, $375)$.

Ottoman medicine was an extension of classical Islamic medical tradition and consequently Ottoman physicians were familiar with, and made use of, classical Greek and Roman medical books in their translated and modified Arabic form. The medical material comprised the simple drugs (materia medica) and the pharmacopoeia containing the compound drugs (akrabadin) and were most popular works. (Aydın, 2006, 231; The name Akrabadin was derived from the Greek, "graphizon" and was translated as "krabadin" or "akrabadin" in Arabic and Persian, were the medical books indicated the active ingredients and how they were to be employed. See also, Doğan, 2012, 104). The impact of İbn-i Sina, whose works deeply influenced both Eastern and Western medicine, had a strong influence upon Ottoman physicians (This influence is still felt today and some folk medicine made from honey, henna and opium is used and known as Ibn-i Sina's compound. Cunbur, 1986, 63). Considering this tradition, it is not surprising that Ottoman physicians knew of the mithridaticum compound from the books of Ibn-i Sina and from other Islamic physicians, and that they recorded this compound in their studies. But the variations of the word in the Ottoman medical works resulted in a variety of discussions. The overwhelming majority of the modern medical historians tend to interpret the continuing mesir paste tradition and its festivals within this framework. In this context it is suggested that the word mithridaticum over time was shortened to "misir" and eventually became the word "mesir" (Bayat, 1981, 9). But Nihat Yörükoğlu claims mesir resembles not mithridaticum but tiryak and the mesrozitosa mentioned in Ibn-i Sina's El Kanun fi't-Tibb and that it might have been derived from the compound noun "mestrozitos", which consisted of the words "mesr" and "sitos" (Yörükoğlu, 1982, 179). A further view is that mesir paste was a different version of mithridaticum which reached Ottoman territory from Venice (Bayat, 1981, 11).

Mesir paste, which had a prominent place in Ottoman traditon, is sometimes confused with the paste called "Nevruziye". Nevruziye originated in a rather old Iranian and Central Asian Turkish tradition and every year on March the $21^{\text {st }}$ this paste which had been prepared by the chief physicians in the palace dessert kitchens was served to the Sultan and to the leading statesmen (Kongaz, 1984, 108). Although mesir is confused with nevruziye (For the compound of the paste prepared at Newroz see: Yahyaoğlu, 2005, 26-27) since the mesir festivals begin on the first day of spring, they are quite different from each other (Alptekin, 2011, 215). The letters sent by the Minister of the Hafsa Sultan Foundation to the mutawalli and the edicts of Ottoman Sultans show that mesir is different from nevruziye both in terms of its contents and in its use for medical purposes (Tuser, 1960, 2099; Terzioğlu, 1999, 375).

Mithridaticum compounds are recorded in the Ottoman sources on various occasions. One of these sources is the "Mücerrebname" by Şerefeddin Sabuncuoğlu, who had quite an uncommon profile when compared to others of his time. Following the principle of "experiment is the evidence of reality" it was only after he had tested the drugs and the treatment methods many times and become convinced of the results, that he recorded them in his books. (Şerafeddin Sabuncuoğlu conducted experiments on himself, he tried to test the effect of the tiryak he had concocted by having his finger bitten by a venomous snake, Sabuncuoğlu, 1992, 23) The contents of the mesriditos mentioned in this book and the compound of mithridaticum and that of tiryak given by Ibn-i Sina are similar. The only difference is in the number of the ingredients in tiryak, which is understandable when its use is considered (For the ingredients of the compound see also; Yörükoğlu, 1982, 186; Sabuncuoğlu, 1999, 28-29). Among the tiryak pastes made for the Sultan in the Topkap1 Palace Dessert Kitchen were those "ma'cun- $i$ mesrititus-mithridaticum" compounds recorded in the "dessert kitchen register". Some 53 of the 
61 ingredients used in the mithridaticum prescription recorded in this register are the same as those in Ibn-i Sina's compound, and 54 of them are the same as those given in Al-Antaki's mixture, the only difference is that while both Ibn-i Sina and Al-Antaki's prescriptions contain skink, the compound produced in the Palace dessert kitchen register does not include this ingredient (Terzioğlu, 1992, 28). It appears that the Ottoman court physicians also altered and improved the mithridaticum compound through adding new ingredients to it (Terzioğlu, 1999, 375-376) The Ottoman mithridaticum compound is recorded not only in the medical studies of the period but also in Ottoman chronicles and other books. In the "Mevaidü'n-Nefais $f i$ Kavaidi'l-Mecalis" by Mustafa Ali of Gelibolu, mithridaticum is recorded as "misriditus" (Gelibolu'lu Mustafa Ali, 1978, 338). But Bayat states that Orhan Şaik Gökyay, who published the book transcribed into the Latin alphabet, described it as a word which couldn't be found in the dictionaries because of a clerical error made by the scribe (Bayat, 1998, 71). Likewise an Ottoman chronicle, the "Tarih-i Selaniki" mentions mithridaticum. This chronicle records the interrogation of Koca Şüca, the physician, by a committee under the leadership of the Chief physician Garsüddinzade, as Koca Şüca was held responsible for the death of Ferhad Pasha in 1575 because of the rumours that the "mesirditos" which was prescribed by Koca Şüca caused Ferhad Pasha's death (It is quite interesting to see the word "mesirditos" turn into "mesir" on the same page of the book. Bayat, 1998, 77; Mustafa Selaniki Efendi, 1999, 111 Evliya Çelebi notes the broad spectrum of the paste's use in Istanbul as a remedial medicine and for a variety of purposes. Evliya Çelebi gives the number of paste sellers in Istanbul as 500 and the shops as 200. Evliya Çelebi Seyahatnamesi, 2003, 262. Although herbalists played a vital part in the production of medicine and paste, the negligence of the sellers sometimes greatly troubled the pharmacists who bought their ingredients from them, Mat, 1993, 314).

It is to be noted that most Ottoman medical historians associated mesir paste with the mithridaticum mentioned in the sources above and they even suggested that mesir was derived from mithridaticum. Today there is discussion concerning Merkez Efendi, who was most closely identified with the mesir tradition and who it is claimed was the inventor of mesir paste. According to the common belief in this matter, Hafsa Sultan, the mother of Süleyman the Magnificent, demanded of Sünbül Efendi that he find a successor for the zawiya of the complex which had recently been completed, and, upon his recommendation of Merkez Efendi, he was sent to Manisa and in the mental hospital there he invented the paste which was made from 41 ingredients. Further, the tradition of throwing tiny packages of paste every Newroz (March the $21^{\text {st }}$ ) is believed to have been started by Merkez Efendi ("Merkez Efendi", Türk Dünyası Ortak Edebiyatı: Türk Dünyası Edebiyatçlları Ansiklopedisi, 2005, 331; Tuser, 1960, 2098; Pehlivan 2011, 38). The recovery of Kanuni's mother due to the efficacy of Merkez Efendi's compound resulted in the distribution of such a beneficial and effective medicine on the first day of spring (nev-ruz) the equinox when the day and night are of equal length (Ünver, 1983, 44, For detailed explanations considering mesir paste and its festivals as an extension of much older Anatolian Pagan culture see also: Bayat, 1981, 11). Nihat Yörükoğlu citing the Province of Aydın Yearbook, suggests that the reason for the commencement of the mesir festivals was to enable the city located on a hillside to prosper and to permit it to move down to the plain, which was more convenient (Yörükoğu, 1982, 184-185).

Ali Haydar Bayat states that even though the people associated both mesir paste and the mesir festivals with Merkez Efendi, this doesn't reflect the truth. Bayat states that after the death of his Sheikh, Sümbül Efendi in 1529, Merkez Efendi left Manisa and became the first head (postnişin) of the tekke in İstanbul and the construction of the Manisa hospital was only completed in 1539, and he also underlines the absence of any kind of contemporary information indicating Merkez Efendi had any career as a physician (Bayat, 1993, 14; Demirci, 2003, 75. 
For detailed information concerning Merkez Efendi see also: Merkez Efendi Sempozyumu, 1988). He also adds that Merkez Efendi was first mentioned as the inventor of mesir paste, a belief supported by accounts of the folk, in the Province of Aydin Yearbook, that is dated 1870 and that later, based upon this information, there came the presentation of Merkez Efendi as its inventor (Bayat, 1993, 14; Aydin Vilayeti Salnamesi, 1304, 330-333). It may be the reason that mesir paste and its festivals was given to Merkez Efendi was due to the notion that people who have attained a certain level of holiness themselves possessed curative powers (Yahyaoğlu, 2005, 23).

Putting to one side discussion as to the origin of the mesir traditon and the identity of its inventor, it seems absolutely certain that the preparation and distribution of this important paste held an important place in Ottoman culture. After the 41 spices and ingredients provided by the mutawalli of the Complex were mixed in the due quantities, under the supervision of the Chief Physician of the Hospital, they were ground in large mortars. Later there were only mental patients in this hospital and this task of grinding the paste was left to them. People believed that paste ground by mentally ill patients was more curative (Bayat, 1981, 19). This thought probably originated from the Islamic belief that mentally impaired patients are truly innocents. After the mixture was boiled in containers and was then solidified as a paste, the young men of Manisa would volunteer to help with the distribution, and bars of paste were wrapped in small pieces of paper. They were allowed to eat as much of the paste as they wished but no water was put in the room so that they couldn't exceed limits (Yahyaoğlu, 2005, 31).

Apart from the mesir festivals, the candy makers also prepared and sold mesir paste (Bayat, 1981, 20). The herbalist's shops selling folk medicine and candy in the Manisa Bazaar and especially in the neighbourhoods together with groceries were quite common (Emecen, 2006, 71). We also learn from Evliya Çelebi that medicines and paste were sold in a place called Tahtakale in Manisa (Akçiçek, 1982, 16). But since the paste which was thrown down from a mosque rooftop had a spiritual meaning for the people and was considered to possess more curative power, this paste was more in demand (Tuser, 1960, 2098). People who failed to catch the paste during mesir festivals and who feared venomous animals (snakes-centipedes) bought this paste from those who had succeeded, and they were mostly overcharged and, according to rumours, there were even cases where a bar of this paste was sold for the price of a donkey (Uluçay, 1943, 7). When it came to the time appointed for the mesir festivals, Newroz was particularly preferred, as being the time to clean and strengthen the body after the winter and to prepare it for the spring (Güven, 2010, 2).

The benefits of this highly popular paste were as follows: those who ate the paste wouldn't be bitten by snakes or centipedes, those seriously ill people who ate the paste which was distributed in Newroz would get well, healthy people wouldn't fall sick, girls who had reached the age of marriage would marry, childless women would give birth and sick children would get well within the year. It was also believed to have aphrodisiac qualities, as well as its positive effects on those suffering from psychiatric and neurological diseases (Baytop, 1963, 17). The paste was introduced as a kind of panacea and the people's faith in it continued until the ending of the Ottoman state. In this context it is striking to note commercial leaflets were prepared that emphasized the sedative and refreshing effects of the widely used mesir as a medicine (Sar1, Dinç, \& Altıntaş, 1999, 85).

The main ingredient of mesir is sugar, i.e. saccharose and what really intensified its importance were its spices. Accordingly the historical sources emphasize its medical benefits rather than mentioning it as a foodstuff (Nergiz, 1994, 30). However, the paste which is probably high in antioxidants since many spices are used in its production is preferred by those consumers who are careful to make healthy foodchoices (Arslan, 2004, 54; Güven, 2010, 2). 
The 41 ingredients of mesir paste are; cloves, allspice, ginger, zedoary, cream of tartar, coriander, galanga, cubeb, coconut, anise, cassia, mastic, saffron, cardamom, samli sasli, vanilla, mrytus, orange peel, sugar, galibarta, spring water, cinnamon, akt-ı karha, china root, mustard, elixir, indigo, liquorice honey, theriac, yellow myrobolani, fennel, cumin, turmeric, cinnamon flower, Indian flower, black cummin, darıfülfül, rhubarb and citric acid (Ünver, 1983, 45; for detailed information about the chemical characteristics and combination see also: H1d11, 1994, 32-40). These 41 ingredients were believed to help people escape from 41 troubles, aches and afflictions (Baytop, 1963, 18; Eyüpoğlu, 2007, 252). Bayat says that the Ottoman physicians adopted the 60 ingredients of Ibn-i Sina, but the number of the ingredients was reduced, and the paste was then composed of 41 spices and herbs, since they had difficulty in acquiring some ingredients of Ibn-i Sina's compound from the flora of Anatolian; together with the belief that the formula containing 41 ingredients originated from the mystical importance of the number 41 for people (Bayat, 1993, 13; 1998, 76).

According to the information on the food label of mesir paste that is on the market today, some paste contains 20-25, some 30-31 and the other 40-41 spices (Eyüpoğlu, 2007, 253; Güven, 2010,2). Today glucose syrup is used to sweeten mesir. The patent rights, production and distribution free of charge, or for sale, belong to "The Promotion of Manisa and Mesir and Tourism Union". The annual production capacity is about 500.000 tons, and while most is sold on the domestic market, 2 or $3 \%$ of the paste is exported (In the 1520's honey and grape juice were used as sweeteners. See: Güven, 2010,2).

Putting to one side the controversy as to whether Merkez Efendi was the real inventor of mesir and the mesir festivals, the point is that the ongoing tradition remains focussed on Merkez Efendi and it is typically understood in this form. These expressions shaped around the theme of Merkez Efendi play a significant part in the formation of the paste's cultural aspect and its continuation. In this context Merkez Efendi and the mesir festivals retain their popularity and constitute an important phenomenon of Turkish folklore and traditions.

\section{REFERENCES}

Akçiçek, E. (1982). "Manisa'da Attarlık”. I. Mesir Konferansları 20-30 Nisan 1982, 15-19. Manisa: Manisa Turizm Derneği Yayınları.

Alptekin, A. B. (2011). Halk Bilimi Araştırmaları. Ankara: Akçağ Yayınları.

Arslan, M. (2004). "Halk Kültürünün Değişim Boyutu ve Mesir Şenlikleri”. Halk kültüründe Değişim Uluslararası Sempozyum Bildirileri, 17-18-19 Aralık 2004, 49-56. Kocaeli: Kültür ve Turizm Bakanlığı, Kocaeli Üniversitesi.

Arslan, M. (2007). Roma'nın Büyük Düşmanı Mithradates VI Eupator. İstanbul: Odin Yayınları.

Aydın, E. (2006). Dünya ve Türk Tıp Tarihi. Ankara: Güneş Kitapevi.

Aydın Vilayeti Salnamesi. İstanbul 1304.

Bayat, A. H. (1998). “Mithridates’ten Mesir'e”. Yeni Tıp Tarihi Araştırmaları, Cilt IV, 67-78. İstanbul.

Bayat, A. H. (1993). "Mesir Macunu ve Alternatif Tıp". 453. Mesir Şenlikleri, Panel Konuşmaları, 11-15. 28 Nisan 1993. Celal Bayar Üniversitesi, Manisa.

Bayat, A. H. (1981). Manisa Mesir Bayramı ve Darüşşifası. Manisa: Manisa Turizm Derneği Yayınları.

Baytop, T. (1963). Mücerreb-name. İstanbul: İstanbul Üniversitesi, Tıp Fakültesi Yayınları.

Baytop, T. (1999). Türkiye'de Bitkiler ile Tedavi. İstanbul: Nobel Tıp Kitapları.

Cunbur, M. (1986). “İbni Sina’nın Kültürümüzdeki Yeri”. İbni Sina 980-1037, 55-63. İbni sina Haftas1 Kutlamaları, Ankara.

Dalby, A. (2004). Tehlikeli Tatlar Tarih Boyunca Baharat. İstanbul: Kitap Yayınevi.

Demirci, M. (2003). “Merkez Efendi'nin Yetiştiği Kültür Çevresi”. Kubbealtı Akademi Mecmuası, Yı1: 
32, I, 75-80. Ocak. İstanbul.

Doğan, Ş. (2012) XV.-XVIII. Yüzyıllar Arasında Anadolu Sahasında Türkçe Yazılmış Tıp ve Eczacılık Sözlükleri. IV. Uluslararası Dünya Dili Türkçe Sempozyum Bildirileri, Cilt II, 103-114. Muğla Üniversitesi, Ankara.

Emecen, F. (2006). Tarihin İçinde Manisa. Manisa: Manisa Belediyesi Kültür Yayınları.

Evliya Çelebi Seyahatnamesi (2002). Cilt I. Haz. Robert Dankoff, Seyit Ali Kahraman \& Yücel Dağl1. Yapı Kredi Yayınları.

Eyüpoğlu, İ. Z. (2007). Anadolu Halk İlaçları. İstanbul: Derin Yayınları.

Gelibolu'lu Mustafa Ali. (1978). Yay. Haz. Orhan Şaik Gökyay. Mevaidü’n-Nefais fi Kavaidi'l-Mecalis, Tercüman 1001 Temel Eser. Cilt. II. İstanbul.

Güven, A. (2010). Mesir Macunun Antioksidan Aktivitesinin ve Reolojik Özelliklerinin Belirlenmesi. Yayınlanmamış Yüksek Lisans Tezi. İstanbul Üniversitesi, İstanbul.

Hıdıl, Y. (1994). "Mesir Macunun Kimyasal Bileşimi”. 454. Mesir Konferanslarl 20-24 Nisan 1994, 3240. Manisa: Manisa Turizm Derneği Yayınları.

İbni Sina. (1986). El-Kanun Fi’t-Tıbb (Beşinci Kitap). Çev. Esin Kahya. Atatürk Kültür Merkezi, Ankara.

Mat, A. (1993). “Osmanlı Döneminde İstanbul'da Zehirler ve Zehirlenmeler”. III. Türk Tıp Tarihi Kongresi, 313-318. İstanbul: TTK Yayınları.

Mayor, A. (2010). The Poison King. Princeton. Princeton University.

Merkez Efendi Sempozyumu, 1988. Türk Ocağı Denizli Şubesi Yayınları, 27-28 Haziran 1988, Denizli.

Nergiz, C. (1994). “Gida Olarak Mesir Macunu”. 454. Mesir Konferansları 20-24 Nisan, 30-31. Manisa: Turizm Derneği Yayayinlarc.

Pehlivan, G. (2011). “M. Nuri Yörükoğlu'na Göre Manisa'da Tarikatlar ve Tekkeler”. Sufi Araştırmalarl, Cilt. II/4, 11-56. Manisa: Mevlana Düşüncesi Araştırmaları Derneği Yayınları.

Sabuncuoğlu, Ş. (1992). Cerrahiyyetü'l-Haniyye. Cilt I. Çev. İlter Uzel. Ankara: TTK Yayınları.

Sabuncuoğlu, Ş. (1999). Mücerreb-name. Çev. İlter Uzel-Kenan Süveren. Ankara: Atatürk Kültür Merkezi Yayınları.

Sarı, N, Dinç, \& Altıntaş, A. (1999). “1910-1928 Yılları Arasında Yayınlanan Eski Harfli Reklamlarda Türk Müstahzâratçılığı”. II. Türk Tıp Tarihi Kongresi. Cilt II. 85-130. Ankara: TTK Yayınları.

Selaniki Mustafa Efendi (1999). Tarih-i Selaniki. Cilt I. Haz. Mehmet İpşirli. Ankara: TTK Yayınları.

Terzioğlu, A. (1992). Helvahane Defteri ve Topkapı Sarayında Eczacılı. İstanbul: Arkeoloji ve Sanat Yayınlar1.

Terzioğlu, A. (1999). “Topkapı Sarayında Helvahane'de İlaçların İmaline Dair Bir Yazma Eser ve Buna Göre İki Mithridatikum Reçetesi”. Uluslarası Üçüncü Türk Kültürü Kongresi Bildirileri 25-29 Eylül 1993, Cilt II, 365-375. Ankara: Atatürk Kültür Merkezi Yayınları.

Tez, Z. (2010). İlaç ve Parfümün Sihirli Dünyası. İstanbul: Hayy kitap.

Totelin, L. M. V. (2004), “Mithradates; Antidote, A Pharmacological Ghost”. Early Science and Medicine, 9/1, 1-19. Amsterdam.

Tuser, H. (1960). “Manisa'da Mesir Bayramı”. Türk Folklor Araştırmalarl, Cilt. VI, 128, 2097-2100. İstanbul.

Uluçay, Ç. (1943). “Manisa'nın En Eski İki Adeti (Namaz Gecesi ve Mesir)”. Gediz, 6-7. Manisa: Halkevi Yayinı.

Uzel, İ. (1986). “Kanun Eserinin Beşinci Cildi: Akrabadin”. İbn-i Sina, Anma ve Tanıtma Toplantılarl, 980-1037. Ankara: Kültür ve Turizm Müdürlüğü Yayınları.

Ünver, S. (1983). “Tıp Tarihi Yıllığı”. İstanbul Üniversitesi, Cerrahpaşa Tıp Fakültesi Yayınları, Cilt. II, 12-18. İstanbul.

Vahid,T. (1324). “Edviye, Tedavi ve Eczacılığın Tarihiyesi”. Eczacı, Sayı. I. 3-4. 2-8. İstanbul.

Yörükoğlu, N. (1982). "Mesir Sözcüğünün Etimolojisi, Mesir'in Terkibi ve İhdas Sebepleri”. Ankara Tıp Bülteni, Cilt $I V .171-188$. Ankara, 1982. 